\author{
기류건조기를 이용한 고수분 석탄의 건조 특성 \\ 김상도 + · 이시훈 · 임영준 · 최호경 · 임정환 · 전동혁 · 유지호 \\ 한국에너지기술연구원 청정석탄센터 \\ 305-343 대전광역시 유성구 가정로 152 \\ (2011년 4월 18일 접수, 2011년 5월 11일 채택)
}

\title{
Drying Characteristic of High Moisture Coal using a Flash Dryer
}

\author{
Sang Do Kim ${ }^{\dagger}$, Si Hyun Lee, Young Joon Rhim, Ho Kyung Choi, Jeong Hwan Lim, Dong Hyuk Chun and Ji Ho Yoo \\ Clean Coal Center, Korea Institute of Energy Research, 152 Gajeong-ro, Yuseong-gu, Deajeon 305-343, Korea \\ (Received 18 April 2011; accepted 11 May 2011)
}

\begin{abstract}
요 약
$5 \mathrm{~kg} / \mathrm{hr}$ 벤치규모 기류건조기를 이용한 고수분 석탄의 건조 특성을 알아보았다. 도착시료 기준으로 원료 석탄의 수 분 함량 및 발열량은 각각 $29.74 \mathrm{wt} \%, 4,270 \mathrm{kcal} / \mathrm{kg}$ 이다. 가스유입온도 및 가스유입속도는 각각 $400-600{ }^{\circ} \mathrm{C}$ 및 $10 \sim 20$ $\mathrm{m} / \mathrm{sec}$ 이다. 원료 석탄의 입자크기는 $1002,000 \mu \mathrm{m}$ 로 분쇄 및 분급하였다. 원료석탄의 수분제거율은 가스유입온도는 증가하고 가스유입속도는 감소할수록 급격하게 증가하였다. 건조석탄의 발열량은 $5,100 ~ 5,900 \mathrm{kcal} / \mathrm{kg}$ 으로 증가하였다. 기류건조를 통한 고수분 석탄 표면에서의 발생하는 화학적인 변화를 알아보기 위하여 FT-IR 스펙트럼 분석을 실시하 였다. 그 결과 하이드록실, 카르복실 및 카보닐 피크에서 주요한 변화가 일어나는 것을 확인할 수 있었다.
\end{abstract}

\begin{abstract}
Drying characteristic of high moisture coal using a $5 \mathrm{~kg} / \mathrm{hr}$ bench scale flash dryer was investigated. Moisture content and heating value of raw coal as received basis were $29.74 \mathrm{wt} \%$ and $4,270 \mathrm{kcal} / \mathrm{kg}$, respectively. Gas inlet temperature and gas inlet flow rate were $400 \sim 600{ }^{\circ} \mathrm{C}$ and $10 \sim 20 \mathrm{~m} / \mathrm{sec}$, respectively. The raw coal was ground and classified to the particle size range of $100 \sim 2,000 \mu \mathrm{m}$. The moisture removal rate of raw coal was dramatically increased with increasing gas inlet temperature and decreasing gas inlet flow rate. The heating value of dried coal was increased to $5,100 \sim 5,900 \mathrm{kcal} / \mathrm{kg}$. To examine the chemical change on the surface of high moisture coal during flash drying process, FTIR spectral analysis was carried out. As a result, major changes in hydroxyl, carboxyl and carbonyl peak was confirmed.
\end{abstract}

Key words: High Moisture Coal, Drying, Flash Dryer, Moisture Removal, Heating Value

\section{1. 서 론}

저등급석탄으로 분류되는 갈탄 및 아역청탄은 전세계 석탄 매장 량의 $50 \%$ 이상을 차지할 정도로 매장량이 풍부하며 가격도 고등급 석탄인 역청탄에 비해 $1 / 4$ 정도로 낮다. 그러나 저등급석탄은 수분 함량이 높아 발전소에 직접 적용할 경우 수분을 증발시키는데 많은 열량이 소요되기 때문에 발전효율 저하를 가져오며, 기공이 발달하 고 산소를 함유한 카르복실기 함량이 높아 자연발화 가능성이 높기 때문에 장기간 저장 및 수송에 한계점을 갖고 있다.

이러한 문제의 해결 방안으로 석탄의 건조를 통해 저등급석탄을 고품위화하기 위한 많은 연구들이 진행되고 있다. 기류건조 방식을 이용한 호주 $\mathrm{BCB}$ (Binderless Coal Briquetting)[1,2], 유중건조 방식 을 이용한 일본 UBC(Upgrading Brown Coal)[3-5], 스팀 유동층을 이용한 독일 WTA(fluidized-bed drying with internal water heat utilization)[6], 유동층을 이용한 미국 $\mathrm{DryFine} \mathrm{TM}^{\mathrm{TM}}$ 공정 [7]이 개발되

\footnotetext{
${ }^{\dagger}$ To whom correspondence should be addressed.

E-mail: sdkim@kier.re.kr
}

었다.

이중 $\mathrm{BCB}$ (Binderless Coal Briquetting) 기술은 기류건조(flash drying) 또는 급속건조를 이용해 석탄을 건조하는 기술이다. 이 기 술은 고온 가스가 고수분 석탄과 직접 접촉하여 건조되는 것으로 체 류시간은 1초 이하로 매우 짧은 접촉 시간 동안 건조가 이루어진다. 기류건조기는 건조시간이 짧고, 별도의 수송장치가 필요 없으며, 장 치가 간단하고 운전과 제어가 비교적 용이하며, 운전 유지보수 비 용이 적고, 건설비가 적게 소요된다는 장점을 가지고 있다[8,9]. 단 점으로는 건조시간이 짧기 때문에 비교적 건조속도가 빠른 물질이 어야만 하며, 입자크기는 작을수록 좋은데 적당한 것은 1,000 $2,000 \mu \mathrm{m}$ 정도로 물질에 따라 응집이 일어날 수 있기 때문에 이에 대한 적절한 대책이 필요하다.

본 연구에서는 벤치 규모의 기류건조기를 이용한 운전온도, 입 자크기 및 유입속도 변수에 따른 수분제거율 및 발열량 변화 특 성을 고찰하였다. 또한 기류건조시 고수분 석탄 표면에서의 화학 적인 변화를 알아보기 위하여 FT-IR 스펙트럼 분석을 사용하 였다. 


\section{2. 실험 방법}

본 실험에 사용한 석탄은 내몽고에서 채굴한 Meng Tai 석탄을 사 용하였다. 실험용 석탄의 공업분석, 원소분석 및 발열량 분석결과를 Table 1에 나타내었다. 수분함량은 $29.74 \mathrm{wt} \%$, 회분은 $10.51 \mathrm{wt} \%$ 이며, 산소함량은 $21.42 \mathrm{wt} \%$ 이다. 발열량은 도착시료기준으로 $4,270 \mathrm{kcal} / \mathrm{kg}$ 이고, 건조탄 기준으로 $5,730 \mathrm{kcal} / \mathrm{kg}$ 이다.

고수분 석탄을 건조하기 위한 실험장치로 Fig. 1과 bench 규모의 기류건조기를 설치하였다. 실험장치는 고온가스 공급을 위한 LPG 버너, 원료 석탄 공급 피더, 고수분 석탄의 건조가 이루어지는 수직 관, 기체와 고체를 분리하기 위한 사이클론, 여과집진장치 등으로 구성되어 있다. 수직관의 직경은 $40 \mathrm{~mm}$, 높이는 $5,000 \mathrm{~mm}$, 처리 량은 $5 \mathrm{~kg} / \mathrm{hr}$ 규모이다.

실험은 LPG 버너를 이용해 고온가스를 생성시키며, 조절한 온도 에 도달하면 고수분의 석탄을 공급 한다. 고수분 석탄은 수직관을 통해 이송되면서 건조가 이루어지며, 싸이클론에서 포집되어 하부

Table 1. Analyses of coal sample

\begin{tabular}{lc}
\hline \hline Coal Name & Meng Tai \\
\hline Proximate analysis (wt $\%)$ & 29.74 \\
Moisture & 27.83 \\
Volatile matter & 10.51 \\
Ash & 31.92 \\
Flixed carbon & \\
Ultimate analysis $(w t \%)$ & 62.73 \\
Carbon & 4.11 \\
Hydrogen & 0.95 \\
Nitrogen & 0.28 \\
Sulfur & 21.42 \\
Oxygen & \\
Heating value analysis $(\mathrm{kcal} / \mathrm{kg})$ & 4,270 \\
As received base & 5,730 \\
Dry base &
\end{tabular}

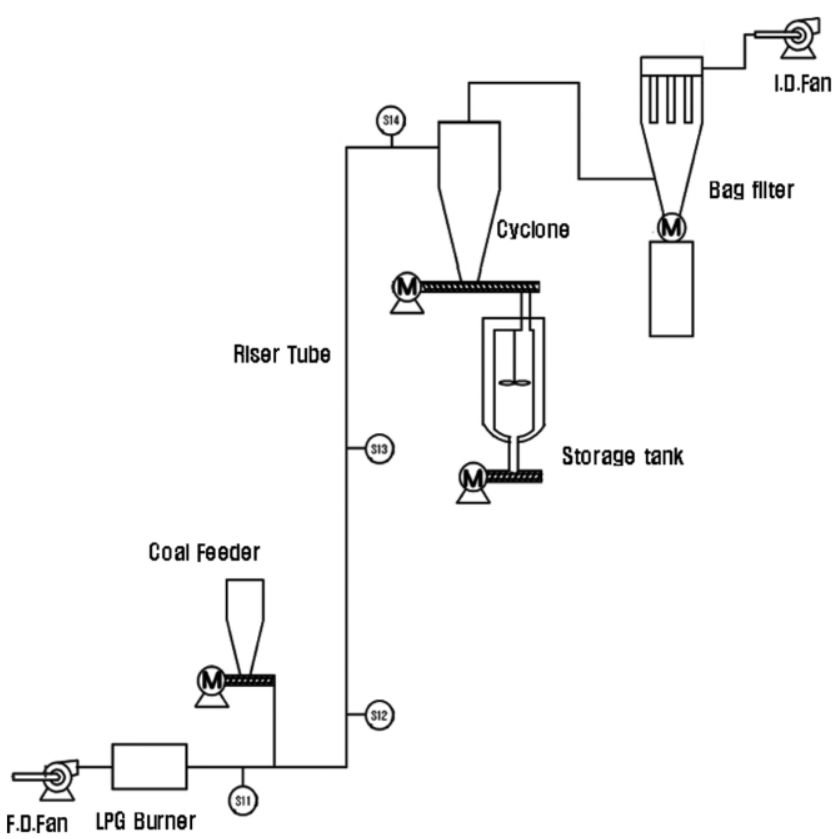

Fig. 1. Experiment equipment.
의 포집탱크에 저장이 된다.

가스 유입온도는 원료 석탄이 공급되는 피더 전단의 측정값을 이 용하였고, 온도 범위는 $400 ~ 600{ }^{\circ} \mathrm{C}$ 로 하였다. 수직관을 통과하는 가스 유입유속은 $10 \sim 20 \mathrm{~m} / \mathrm{sec}$ 가 되도록 유량을 조절하였다.

원료 석탄은 분쇄/분급을 통해 일정범위의 입자크기를 갖도록 준 비되었다. 실험조건에 따라 입자크기 범위는 $100 ~ 300 \mu \mathrm{m}, 300-500 \mu \mathrm{m}$, $500 \sim 1,000 \mu \mathrm{m}, 1,000 \sim 2,000 \mu \mathrm{m}, 100 \sim 2,000 \mu \mathrm{m}$ 범위 등으로 실험을 수행하였다. $100 \sim 2,000 \mu \mathrm{m}$ 로 실험한 경우 건조탄을 4 단계로 분급 하여 각 입자크기별로 수분함량 및 발열량 등을 측정하였다. 수분 함량 및 발열량은 실험 후 바로 측정을 실시하였다.

수분함량 측정은 Karl Fischer 적정법을 이용한 $841 \mathrm{KF}$ Titrando (Metrohm사, 스위스), 발열량 측정은 Bomb Calorimeter(Parr Model 6400EF, 미국), 공업분석은 TGA 701 Thermogravimeter(LECO Co., 미국), 원소분석은 TruPsec Elemental Analyzer(LECO Co., 미국), 황 분석은 SC-432DR Sulfur Analyzer(LECO Co., 미국)를 사용하 였다.

\section{3. 결과 및 검토}

Table 2는 건조된 석탄의 수분함량 결과를 나타낸 것이다. 입자크 기는 $100 ~ 2,000 \mu \mathrm{m}$ 범위로 하였는데, 실험 종료 후 건조 석탄을 4 단계로 분급하여 수분함량을 측정하였다. 전체 입자크기 범위에 대 한 수분함량은 유입온도에 따라 6.99 6.22 wt\%로 큰 차이가 없었 다. 그러나 4단계로 분급한 입자크기별 수분함량 측정 결과 유입온 도 및 입자크기에 따라 수분함량이 최소 $4.92 \mathrm{wt} \%$ 에서 최고 9.44 $\mathrm{wt} \%$ 로 차이를 나타내었다.

Table 3은 건조탄의 공업분석, 원소분석, 발열량 분석 결과를 나 타낸 것이다. 건조탄의 수분함량은 $7 \mathrm{wt} \%$ 이하로 감소하였으며, 휘 발분, 회분 및 고정탄소는 상대적으로 원료 석탄에 비교하여 증가 하였다. 원소분석결과를 보면 산소함량이 약간 감소하는 것으로 나 타났다. 이는 석탄의 수분을 형성하고 있는 하이드록실기, 카르복실 기 및 카보닐기 등이 감소하기 때문인 것으로 판단되는데, 후에 설 명할 FT-IR 분석 결과를 통해서 확인할 수 있었다.

Table 4는 수분이 없는 조건에서 공업분석 결과를 나타낸 것이다. 원탄의 휘발분 함량이 $52.39 \mathrm{wt} \%$ 인데, 건조후에는 휘발분 함량이 $43 \mathrm{wt} \%$ 로 약 $10 \mathrm{wt} \%$ 정도 감소한 것으로 나타났다. 이는 고수분 석탄에 포함되어 있는 휘발분이 고온가스와 접촉하면서 일부 열분 해가 되어 감소하는 것으로 판단된다.

Fig. 2는 석탄입자크기별 건조된 석탄의 수분제거율 및 발열량을 보여주고 있다. 초기 원료 석탄은 석탄 입자를 크기별로 4단계로 분 급하여 실험을 실시한 것이다. 가스 유입온도는 $400{ }^{\circ} \mathrm{C}$, 가스 유입 유속은 $20 \mathrm{~m} / \mathrm{sec}$ 로 수행하였다. 공급되는 석탄 입자크기별에 따라 수분제거율은 크게 변화했는데, $100 ~ 300 \mu \mathrm{m}$ 일 경우에는 $91.4 \%$ 로

Table 2. Moisture content of dried coal

\begin{tabular}{|c|c|c|c|}
\hline $\begin{array}{l}\text { Gas inlet temperature }\left({ }^{\circ} \mathrm{C}\right) \\
\text { Particle size }(\mu \mathrm{m})\end{array}$ & 400 & 500 & 600 \\
\hline $100 \sim 2000$ & 6.99 & 6.64 & 6.22 \\
\hline $100 \sim 300$ & 6.57 & 5.74 & 4.92 \\
\hline $300 \sim 500$ & 7.02 & 6.19 & 5.24 \\
\hline $500 \sim 1000$ & 8.21 & 6.77 & 5.61 \\
\hline 1000 over & 9.44 & 8.11 & 7.53 \\
\hline
\end{tabular}


Table 3. Analysis of dried coal

\begin{tabular}{|c|c|c|c|c|c|c|c|c|c|c|c|}
\hline \multirow{2}{*}{ Sample } & \multirow{2}{*}{ Item } & \multicolumn{4}{|c|}{ Ultimate analysis(wt\%) } & \multicolumn{5}{|c|}{ Proximate analysis(wt\%) } & \multirow{2}{*}{$\begin{array}{l}\text { Heating Value } \\
(\mathrm{kcal} / \mathrm{kg})\end{array}$} \\
\hline & & Moisture & Volatile matter & Ash & Fixed Carbon & Carbon & Hydrogen & Nitrogen & Oxygen & Sulfur & \\
\hline \multicolumn{2}{|l|}{ Raw coal } & 29.74 & 27.83 & 10.51 & 31.92 & 62.73 & 4.11 & 0.95 & 21.42 & 0.28 & 4,269 \\
\hline \multirow{3}{*}{$\begin{array}{c}\text { Inlet gas } \\
\text { temperature } \\
\left({ }^{\circ} \mathrm{C}\right)\end{array}$} & 400 & 6.61 & 38.1 & 14.16 & 41.13 & 61.05 & 4.05 & 1.08 & 19.56 & 0.10 & 5,537 \\
\hline & 500 & 6.54 & 38.19 & 15.17 & 40.1 & 60.05 & 4.03 & 1.08 & 19.56 & 0.11 & 5,586 \\
\hline & 600 & 6.1 & 38.74 & 14.64 & 40.52 & 61.45 & 4.22 & 1.10 & 18.5 & 0.09 & 5,636 \\
\hline
\end{tabular}

*Measuring basis: As received

Table 4. Ultimate analyses at water free basis

\begin{tabular}{cccc}
\hline \hline & Volatile matter(wt $\%)$ & Ash(wt $\%)$ & Fixed Carbon(wt $\%)$ \\
\hline Raw coal & 52.39 & 8.41 & 39.2 \\
$400{ }^{\circ} \mathrm{C}$ & 43.82 & 13.41 & 42.77 \\
$500^{\circ} \mathrm{C}$ & 42.83 & 14.36 & 42.81 \\
$600^{\circ} \mathrm{C}$ & 42.93 & 14.41 & 42.66 \\
\hline
\end{tabular}

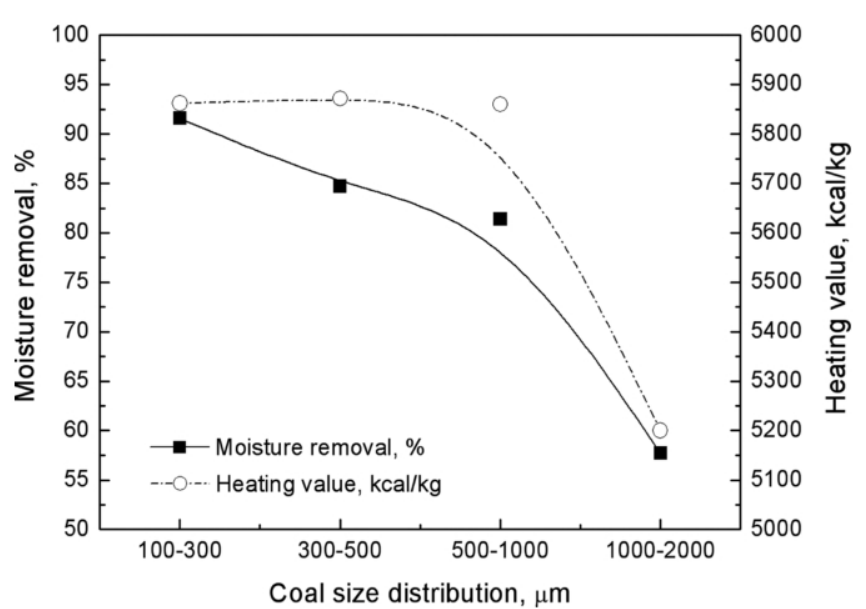

Fig. 2. Moisture removal and heating value at different particle sizes.

높은 수분제거율을 나타내었다. 입자크기가 커질수록 수분제거율은 감소하였는데, $1,000 \mu \mathrm{m}$ 이하에서는 수분제거율이 $81 \%$ 이상을 유 지하였지만, 입자크기가 $1,000 ~ 2,000 \mu \mathrm{m}$ 으로 커지게 되면 수분제 거율이 $57.7 \%$ 로 감소하였다. 이는 석탄 입자크기가 작을수록 표면 적이 더욱 커지게 되고, 큰 입자들에 비해 단위 중량당 건조가 더
잘 이루어지기 때문에 수분제거율이 높게 나타났다.

발열량은 $1,000 \mu \mathrm{m}$ 이하의 입자크기 범위에서는 $5,860 ~ 5,872$ $\mathrm{kcal} / \mathrm{kg}$ 로 유사하게 나타났지만, $1,000 \mu \mathrm{m}$ 이상의 입자크기 범위에 서는 $5,130 \mathrm{kcal} / \mathrm{kg}$ 로 급감하였다. 석탄의 발열량은 입자크기보다는 수분함량에 따라 결정되며, 입자크기가 커질수록 수분제거율이 작 아지기 때문에 발열량은 감소하는 것으로 판단된다.

Fig. 3은 유입온도와 입자크기분포에 따른 수분제거율 및 발열량 결과를 보여주고 있다. 원료 석탄 입자크기는 $100 ~ 2,000 \mu \mathrm{m}$ 이며 건 조후 4단계로 분급하여 수분함량 및 발열량을 측정한 결과이다. 유 입가스온도가 증가할수록 수분제거율은 서서히 증가하고 있는데, 유입온도가 $400{ }^{\circ} \mathrm{C}$ 일 경우 건조탄 입자크기가 $1,000 \mu \mathrm{m}$ 이상부터 $100 \sim 300 \mu \mathrm{m}$ 로 감소함에 따라 수분 제거율은 $68.3 \%$ 에서 $77.9 \%$ 로 증가하였고, 유입온도가 $500{ }^{\circ} \mathrm{C}$ 일 경우 건조탄 입자크기가 $1,000 \mu \mathrm{m}$ 이상부터 $100 ~ 300 \mu \mathrm{m}$ 로 감소함에 따라 수분제거율은 $72.7 \%$ 에서 $80.7 \%$ 로 증가하였다. 유입온도가 $600{ }^{\circ} \mathrm{C}$ 일 경우 건조탄 입자크기가 $1,000 \mu \mathrm{m}$ 이상부터 $100 \sim 300 \mu \mathrm{m}$ 로 감소함에 따라 수분제거율은 $74.7 \%$ 에서 $83.4 \%$ 로 증가하였다. 유입온도가 증가하고 입자크기가 감소함에 따라 발열량은 증가하는 경향을 나타내었고, $5,600 \mathrm{kcal} /$ $\mathrm{kg}$ 이상의 발열량을 갖는 것으로 나타났다. 입자크기가 $1,000 \mu \mathrm{m}$ 이하의 입자크기에서는 발열량의 유입온도에 따라 크게 차이가 나 지 않는 것으로 나타났다. 그러나 $1,000 \mu \mathrm{m}$ 이상의 입자크기에서는 유입온도가 증가함에 따라 발열량이 비교적 큰 차이를 나타내었다.

Fig. 2의 결과에서 보았을 때 입자크기별로 분급하여 건조를 하 게 되면 운전온도가 $400{ }^{\circ} \mathrm{C}$, 입자크기가 $1,000 \mu \mathrm{m}$ 이하인 경우 수 분제거율이 $80 \%$ 이상으로 나타났지만, Fig. 3의 결과는 운전온도가 $600{ }^{\circ} \mathrm{C}$ 이상, 입자크기가 $1,000 \mu \mathrm{m}$ 이하인 경우 수분제거율이 $80 \%$ 이상으로 나타났다. $1,000 \sim 2,000 \mu \mathrm{m}$ 입자크기만 분급하여 실험할
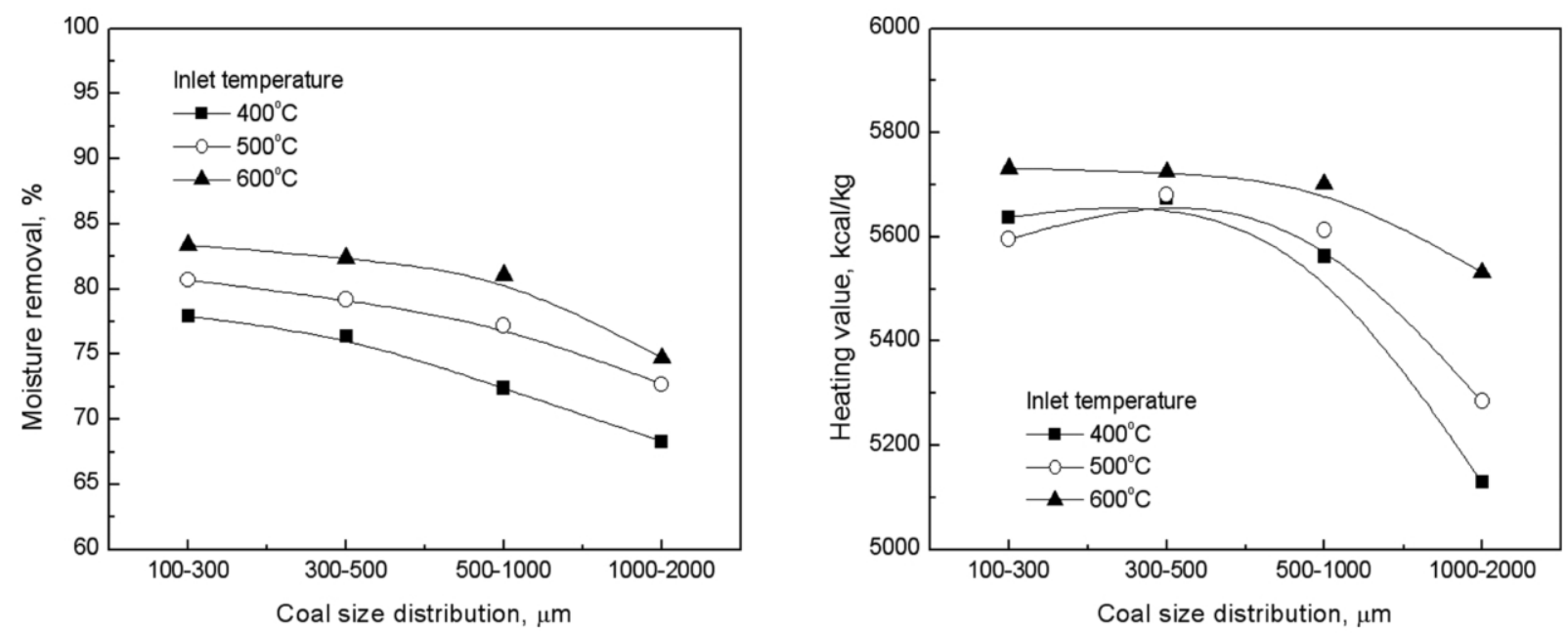

Fig. 3. Moisture removal and heating value to inlet temperature (Gas flow rate : $20 \mathrm{~m} / \mathrm{sec}$ ).

Korean Chem. Eng. Res., Vol. 50, No. 1, February, 2012 

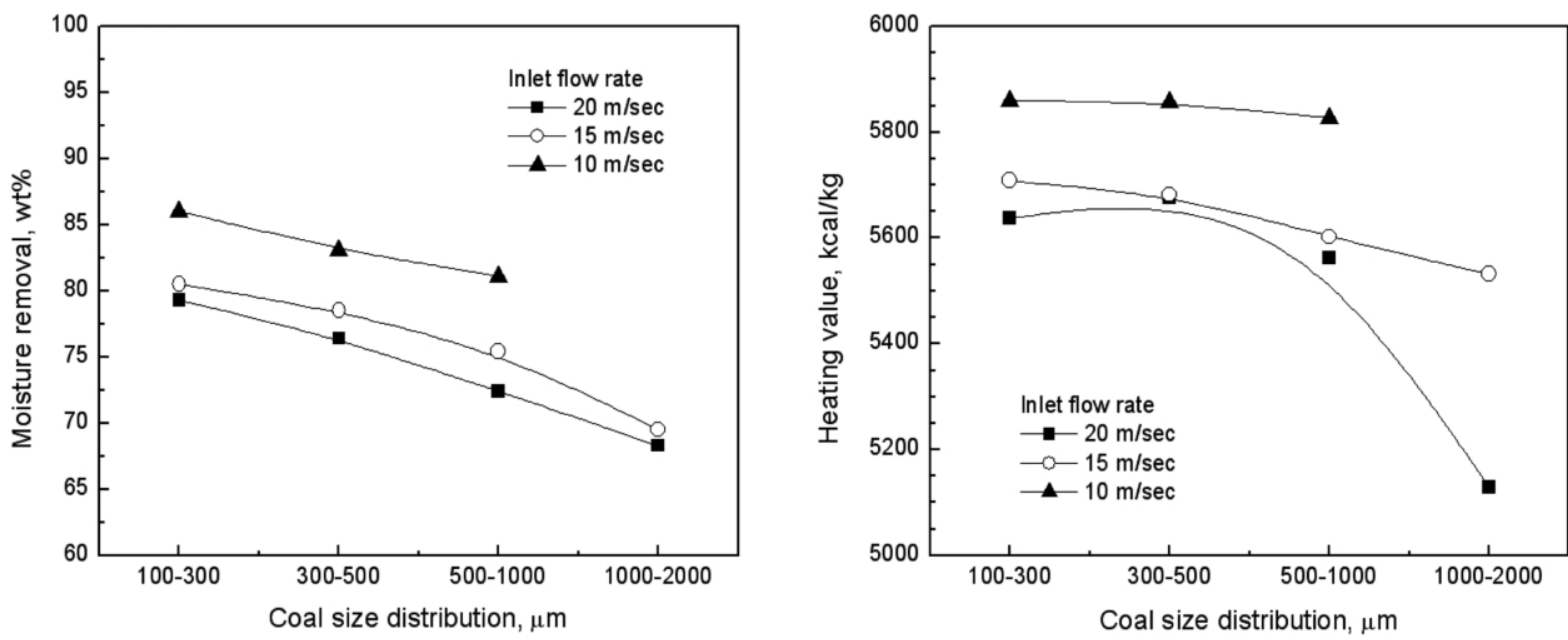

Fig. 4. Moisture removal and heating value to inlet flow rate.

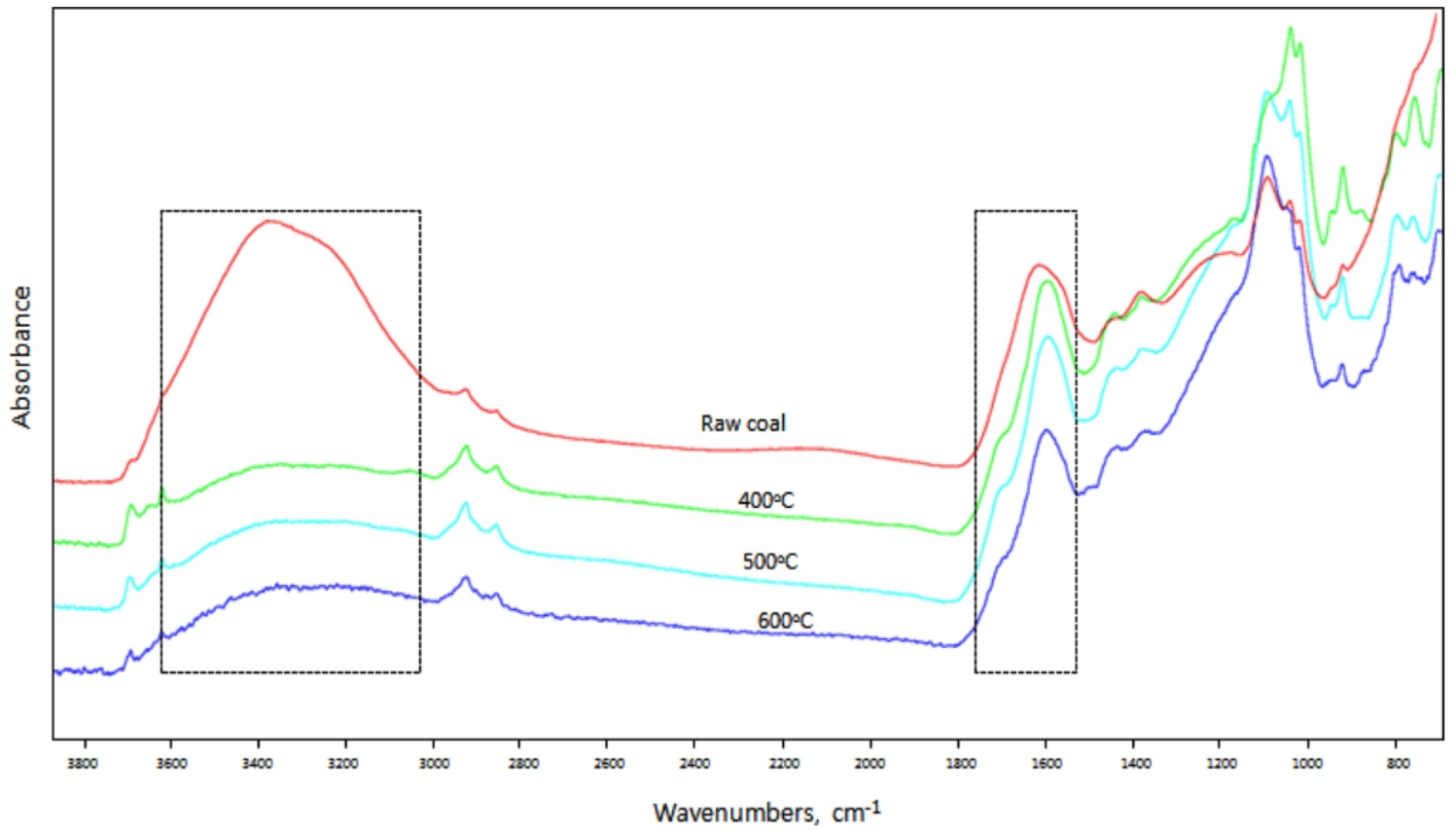

Fig. 5. FT-IR analysis of raw coal and dried coal.

경우 수분제거율은 $60 \%$ 이하로 감소하였지만, Fig. 3 의 결과에서는 $1,000 \mu \mathrm{m}$ 이상에서도 $70 \%$ 정도의 수분제거율을 나타내었다.

이상의 결과에서 보았을 때 높은 수분 제거율을 얻기 위해서는 입자크기를 $1,000 \mu \mathrm{m}$ 이하로 분급하여 건조하는 것이 우수한 건조 효과를 얻을 수 있을 것으로 예상되지만, 분쇄비용 증가와 미분 취 급의 어려움이 발생할 수 있다. 따라서 안정적인 수분제거율을 얻 기 위해서는 입자크기별로 분급을 하는 것보다 $2,000 \mu \mathrm{m}$ 이하로 분 쇄하여 건조하는 것이 보다 바람직할 것으로 판단된다.

Fig. 4는 수직관을 통과하는 가스 유입속도 및 입자크기분포에 따 른 수분제거율 및 발열량 결과를 나타낸 것이다. 유입속도는 $400{ }^{\circ} \mathrm{C}$ 로 일정하게 하고, 수직관을 통과하는 가스 유입속도는 $20 \mathrm{~m} / \mathrm{sec}$ 에 서 $10 \mathrm{~m} / \mathrm{sec}$ 로 변화시킬 때 입자크기 변화에 따른 영향을 살펴본 것이다. 가스 유입속도는 감소하고 입자크기가 감소할수록 수분제 거율은 급격하게 증가하는 경향을 나타내었다. 가스 유입속도가 15 $\mathrm{m} / \mathrm{sec}$ 및 $20 \mathrm{~m} / \mathrm{sec}$ 에서 수분제거율은 입자크기 범위가 $1,000 \mu \mathrm{m}$ 이
상에서 100 300 $\mu \mathrm{m}$ 로 감소함에 따라 $70 \%$ 에서 $80 \%$ 로 증가하였다. 가스 유입속도가 $10 \mathrm{~m} / \mathrm{sec}$ 인 경우 수분제거율은 $500 ~ 1000 \mu \mathrm{m}$ 입 자크기범위에서 $100 \sim 300 \mu \mathrm{m}$ 로 감소함에 따라 $83 \%$ 에서 $87 \%$ 로 증 가하였다. 수직관에서의 가스 유입속도가 감소한다는 것은 동일한 관 길이를 통과하는 입자의 체류시간이 증가한다는 것을 의미한다. 따라서 건조하고자 하는 물질들이 보다 긴 시간 동안 유입가스와 접 촉이 이루어지기 때문에, 가스 유입도가 감소할수록 수분제거율이 증가하는 경향을 나타낸다.

발열량 결과를 보면 가스 유입속도가 $15 \mathrm{~m} / \mathrm{sec}$ 및 $20 \mathrm{~m} / \mathrm{sec}$ 에서 는 유사한 경향을 나타내었지만, $10 \mathrm{~m} / \mathrm{sec}$ 로 감소하였을 경우에는 $5,800 \mathrm{kcal} / \mathrm{kg}$ 이상으로 높게 나타났다.

기류건조에 있어서 유입되는 입자의 체류시간이 증가함에 따라 수분제거율에 보다 효과적이며, 기류건조기 후단의 싸이클론 및 설비 추가에 따라 수분제거율을 향상시킬 수 있을 것으로 예측 된다. 


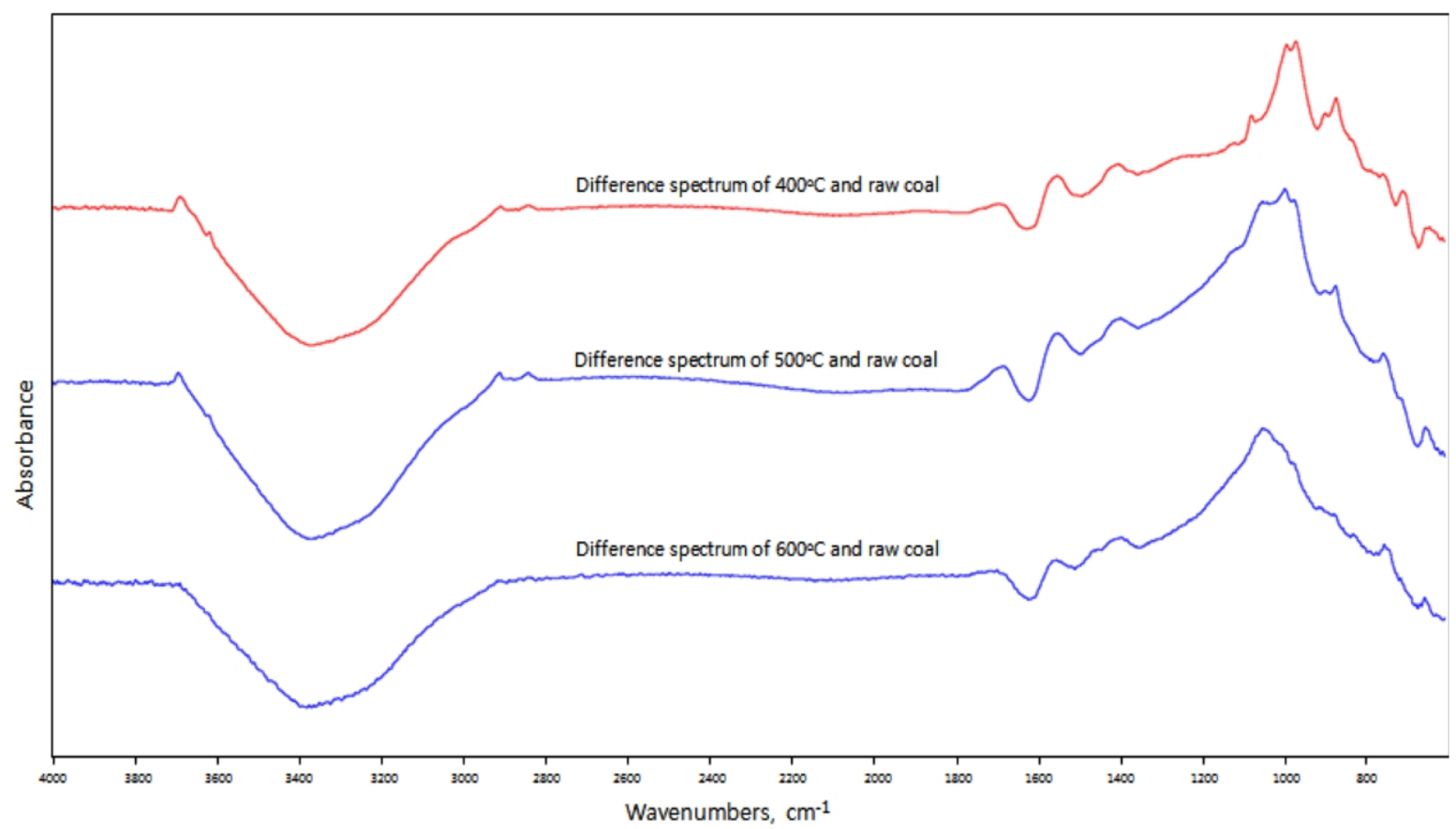

Fig. 6. Difference spectrum of raw coal and dried coal.

기류건조에 의한 고수분 석탄의 표면에서 일어나는 변화를 알아 보기 위하여 FT-IR 스펙트럼 분석을 하였다. Fig. 5는 원료 석탄과 건조 석탄의 FT-IR 분석결과를 보여주고 있다. 석탄에서 수분 및 산 소성분과 관련되는 주요한 피크로 $3,000 ~ 3,700 \mathrm{~cm}^{-1}$ 의 하이드록실 그룹과 카르복실 그룹 및 $1,650 ~ 1,800 \mathrm{~cm}^{-1}$ 의 카보닐 $(\mathrm{C}=\mathrm{O})$ 그룹 등이 있다[10-11]. 수분 제거 공정을 통해 이상의 피크에서 주요한 변화가 일어날 것이라는 예상을 할 수 있다. Fig. 5 에서 볼 수 있는 바와 같이 원료석탄과 기류건조를 실시한 후 $3,000 ~ 3,700 \mathrm{~cm}^{-1}$ 피 크가 크게 감소하여 하이드록실 그룹 및 카르복실 그룹이 크게 감 소하였음을 확인할 수 있다. FT-IR 분석에 의한 $1,650 \mathrm{~cm}^{-1}$ 피크에 서의 카보닐 그룹의 변화를 확인하기 위하여 기류건조의 각 운전온 도에 따른 FT-IR 스펙트럼과 원료석탄 FT-IR 스펙트럼의 스펙트럼 차를 Fig. 6 에 나타내었다. $1,650 \mathrm{~cm}^{-1}$ 피크 부근에서 아래로 볼록 한 모양을 나타내는데, 이를 통해 카보닐 그룹이 감소하였음을 확 인할 수 있다. $3,000 ~ 3,700 \mathrm{~cm}^{-1}$ 의 하이드록실 그룹 및 카르복실 그 룹 피크도 아래로 볼록한 모양을 나타내었다. 일반적으로 고수분 석 탄은 친수성이며, 석탄을 건조한 후에도 수분을 재흡착할 가능성이 높다. FT-IR 분석을 통해서 카르복실 그룹이 감소하는 것으로 나타 났는데, 이와 같은 결과를 토대로 기류건조에 의한 탈카르복실화에 의해 소수성인 탄화수소 그룹으로 분해가 일어나기 때문에 수분의 재흡수 및 자연발화도 방지할 수 있을 것으로 예상된다.

\section{4. 결 론}

벤치규모 기류건조에 의한 고수분 석탄의 건조 특성 실험을 통해 다음과 같은 결론을 도출하였다.

(1) 입자크기가 감소하고 유입속도가 감소(체류시간 증가)할수록 수분제거율이 증가하는 것으로 나타나 기류건조기를 이용한 저등급
석탄의 건조에 있어 입자크기 및 체류시간이 중요한 인자임을 알 수 있었다.

(2) 고수분 석탄에서 $80 \mathrm{wt} \%$ 이상의 높은 수분제거율을 얻기 위 해서는 석탄을 분급하여 $1,000 \mu \mathrm{m}$ 입자크기 이하로 건조하는 것이 바람직하며, 입자크기 범위에 따라 안정적인 수분제거율을 얻기 위 해서는 건조하고자 하는 입자크기 범위를 $2,000 \mu \mathrm{m}$ 이하로 하는 것 이 바람직한 것으로 나타났다.

(3) FT-IR 분석으로 기류건조를 통한 고수분 석탄의 표면에서 하 이드록실 그룹, 카르복실그룹 및 카보닐 그룹이 감소함을 확인할 수 있었다.

\section{감 사}

본 연구는 2009년도 지식경제부의 재원으로 한국에너지기술평가 원(KETEP)의 지원을 받아 수행한 연구 과제입니다.

\section{참고문헌}

1. Mangena, S. J., Korte, G. J., McCrindle, R. I. and Morgan, D. L., "The Amenability of Some Witbank Bituminous Ultra Fine Coals to Binderless Briquetting,' Fuel Process. Technol., 85, 16471662(2004).

2. Keith, C., "Commercial Scale Low Rank Coal Upgrading Using the BCB Process,' 2nd Coaltans Upgrading Coal Forum, Presentation(2010).

3. Sugita, S., Deguchi, T. and Shigehisa, T., "Demonstration of a UBC Process in Indonesia”, 神戶製鋼技報, 56(2), 23-26(2006).

4. Drtin, F. U., Hiromoto, U. and Bukin, D., "Change of Combustion Characteristics of Indonesian Low Rank Coal Due to Upgraded Brown Coal Process,' Fuel Process. Technol., 87, 1007-1011(2006). 
5. Yukio, A., "UBC Process - Upgrading the Future,' 2nd Coaltans Upgrading Coal Forum, Presentation(2010).

6. Klutz, H. J., Moser, C. and Block, D., "WTA Fine Grain Drying - Module for Lignite-Fired Power Plants of the Future," VGB Power Tech Report 11(2006).

7. Sarunac, N., Ness, M. and Bullinger, C., "One Year of Operating Experience with a Prototype Fluidized Bed Coal Dryer at Coal Creek Generating Station,' National energy technology laboratory.

8. Park, M. C. and Kweon, Y. S., "Design of Flash Dryer(I),"
Korean Chem. Eng. Res.(HWAHAK KONGHAK), 12(6), 353360(1974).

9. Park, M. C. and Kweon, Y. S., "Design of Flash Dryer(II)," Korean Chem. Eng. Res.(HWAHAK KONGHAK), 13(1), 33-44 (1975).

10. Solomon, P. R. and Carangelo, R. M., "FT-IR Analysis of Coal," Fuel, 67, 949-959(1988).

11. Li, C.-Z., Advances in the science of victorian brown coal, CRC Press, Australia, 11-84(2004). 